\title{
HŐMÉRSÉKLET KÜLÖNBSÉG VÁLTOZÁSA BETON ÉS VASBETON SZERKEZETEK KÖTÉSI FOLYAMATA SORÁN
}

\section{THE CHANGE OF TEMPERATURE DIFFERENCE IN THE PROCESS OF CONCRETE AND REINFORCED CONCRETE HARDENING PROCEDURE}

\author{
Domonyi Erzsébet $^{1}$, M. Csizmadia Béla ${ }^{2}$, Telekes Gábor ${ }^{3}$ \\ I'Óbudai Egyetem, Bánki Dónát Gépész és Biztonságtechnikai Mérnöki Kar, 1081 \\ Budapest, Népszínház utca 8. domonyi.erzsebet@bgk.uni-obuda.hu \\ ${ }^{2}$ Szent István Egyetem Gépészmérnöki Kar, 2100 Gödöllö, Páter Károly utca 1. \\ csizmadia.bela@gek.szie.hu \\ ${ }^{3}$ Szent István Egyetem Ybl Miklós Épitéstudományi Kar, 1146 Budapest, Thököly út \\ 74.telekes.gabor@ybl.szie.hu
}

\begin{abstract}
The concrete and the reinforced concrete structures capacity have been defined by external loads, environmental effect, mechanical strength and durability. The heat generation of the chemical bond causes the thermal cracks in a case of mass concrete structures and this process is one of the main parameter in the planning and the designing stages. In this paper authors examine the temperature characteristic in a case of reinforced concrete structure and it has been compared with the concrete structure heat distortion. On the other case the impact of rebar have been calculated in a point of view heat distribution modification with the help of finite element modelling.

Keywords: concrete, reinforced concrete, heat generation, durability, risk of cracking

\section{Összefoglalás}

A beton és vasbeton szerkezetek teljesitőképességét a külső terhek, a környezeti hatások, szilárdság és a tartósság befolyásolja számottevően. A tömegbetonoknál a kötés közbeni hőfejlődés hatására kialakuló repedésveszélyt is figyelembe kell venni a tervezéskor és a kivitelezéskor egyaránt. Cikkünkben végeselem modellen vizsgáljuk a tömegbetonokban kialakuló hőmérsékleti viszonyokat vasbeton testeknél és hasonlítjuk össze beton hőmérsékleti jellemzőkkel. Arra a kérdésre keressük a választ, hogy a vasalás mennyire befolyásolja a szerkezetben kialakuló hőmérséklet különbséget.
\end{abstract}

Kulcsszavak: beton, vasbeton, höfejlödés, tartósság, repedésveszély

\section{Bevezetés}

A beton kötési folyamata hőtermelö, amely a cement és víz kémiai reakciójának eredménye. A beton szerkezeti vastagságától függően az utókezelés eltérő lehet. A normál vastagságú - 40 cm-nél kisebb betonok esetében a felszíni vízhütés alkal- mazása elegendő. A nagyobb szerkezeti vastagságú, tömegbetonok esetében egyéb intézkedések is szükségesek a szerkezet korai repedésének elkerülése végett. A tömegbetonok belsejében kialakuló adiabatikus környezet höelvezetési problémákat okoz, mivel a betontest magja és felszíne között kialakuló hőmérséklet-különbség a 
betonban a megengedhető húzófeszültségnél nagyobb értékü feszültséget okoz, amely a szerkezetben repedések kialakulásához vezethet [1].

A tömegbetonok a mérnöki gyakorlatban legtöbbször vasbeton szerkezetek. A beton és betonacél hőtágulási együtthatója közel azonos, így a tömegbetonok esetén a kötéskori hőtágulás számottevő többlet feszültséget nem okoz.

A tömegbetonokban a szerkezet különböző pontjaiban kialakuló kötéskori hömérséklet-különbség hatására keletkező feszültségállapot okozta repedések elkerülése viszont összetett probléma. Figyelembe kell venni tervezéskor a beton összetételét, geometriáját, az utókezeléséről kiemelt figyelemmel kell gondoskodni, ezért a betonösszetétel tervezésekor a kis hőtermelésü cementek használata javasolt.

B. Klemczak és mtsa [2] cikkükben vasbeton tartály és vasbeton híd-elem repedéseinek okait vizsgálják. Kiemelik a megfelelő anyagválasztást, hiszen sokszor a nagyobb szilárdságot biztosító CEM I típusú kötőanyagot írja elő a szabályozás, figyelmen kívül hagyva a magas kötéskori hőfejlődést. Az elöírások szerinti betonkeverék használata nagyobb repedéskockázatot jelent. Numerikus modellel igazolják állításaikat és tüzik ki további feladataikat.

X. Song. és mtsai. [3] arra hívják fel a figyelmet, hogy a vasbeton szerkezeteken kialakuló repeséseken keresztül a betonacélt érő hatások az acél korrózióját elősegíthetik. Vizsgálataik a beton és a betonacél közötti kötéskori kapcsolatot célozzák; az idő függvényében állapítják meg a kötéskori összetartó erőket, nyomószilárdságot a fiatal betonban.

Cikkünkben a beton és vasbeton szerkezetek hőelvezető tulajdonságainak segítségével azt vizsgáljuk, hogy a betontestben kialakuló minimum és maximum hömérsékletek, ill. hőmérséklet- különbség hogyan változik betonacéllal erösített és betonacél nélküli tömegbetonok esetén.

\section{Anyag és módszer}

A vizsgálat során általános rendeltetésü, $\rho_{\mathrm{t}}=2400 \mathrm{~kg} / \mathrm{m}^{3}$ testsürüségü betonkeveréket vizsgáltuk $22,5 \mathrm{~cm}$-es egyenletes osztásközű vasalással és vasalás nélkül (1. ábra).

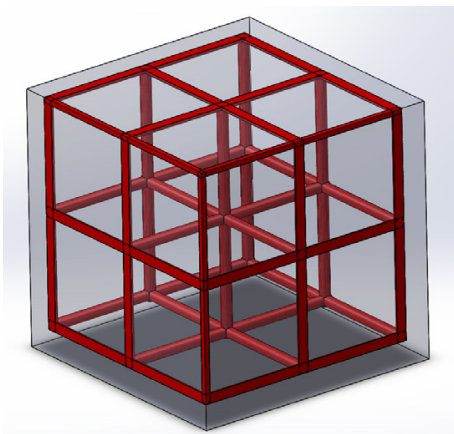

1. ábra. A betonacélok elhelyezkedése a nyolcadmodellben

Az alkalmazott CEM III B 32,5 N jelü cement kis hőfejlesztésü, tömegbetonok készítésére ajánlott, amelynek hőtermelését az 2. ábra szemlélteti.

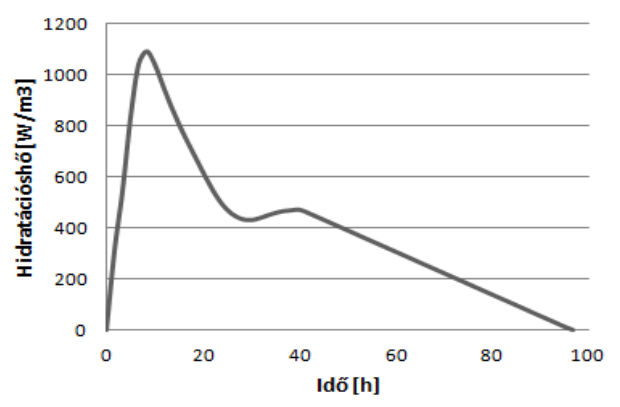

2. ábra. A CEM III B 32,5 N cement hötermelése az idö függvényében

A beton és a betonacél hőtani jellemzöit az 1. táblázatban foglaltuk össze.

A végeselem modellnél kialakított geometria mindkét esetben - beton és vasbeton - 1 méteres élhosszúságú kocka, utóbbinál a $20 \mathrm{~mm}$ átmérőjü betonacélok általános, minimális vasalási feltételeket kielégítö szabály szerint kerültek elhelyezésre. 
1. táblázat. $A$ beton és a betonacél hötani jellemzöi.

\begin{tabular}{|c|c|c|}
\hline Jellemzők & beton & betonacél \\
\hline $\begin{array}{c}\text { Fajhő } \\
{[\mathrm{J} /(\mathrm{kgK})]}\end{array}$ & 1228 & 434 \\
\hline $\begin{array}{c}\text { hővezetési tényező } \\
{\left[\mathrm{W} /\left(\mathrm{m}^{2} \mathrm{~K}\right)\right]}\end{array}$ & 3,5 & 60,5 \\
\hline
\end{tabular}

Mindkét modellt azonos finomságú hálózással és peremfeltételek mellett vizsgáltuk. A kísérlettér meghatározásakor a mérnöki gyakorlatban kialakuló lehetséges hőmérsékleteket és szigetelési / utókezelési megoldások minimum és maximum értékeit vettük figyelembe, így az alábbiak szerint alakult:

- a hőátadási tényező $(\mathrm{h})$ értéke $5 \mathrm{~W} / \mathrm{m}^{2} \mathrm{~K}$ (maximális szigeteléssel ellátott) és 30 $\mathrm{W} / \mathrm{m}^{2} \mathrm{~K}$ (szigeteletlen),

- a környezeti hőmérséklet $(\mathrm{T})$ értéke 5 ${ }^{\circ} \mathrm{C}$ (téli betonozás) és $30{ }^{\circ} \mathrm{C}$ (nyári betonozás).

- A frissbeton bedolgozási hőmérséklete minden esetben $25^{\circ} \mathrm{C}$ volt.

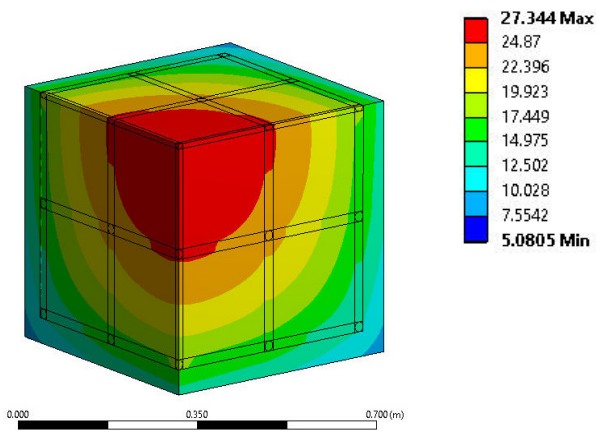

3. ábra. $A$ vasbeton modell szimmetriasíkjában a hömérséklet eloszlás $h=30 \mathrm{~W} /\left(\mathrm{m}^{2} \mathrm{~K}\right)$, valamint $T=5^{\circ} \mathrm{C}$ esetén

$\mathrm{Az}$ adott pillanatokban ébredő hőmérséklet-különbségeket nemlineáris végeselem modell segítségével határoztuk meg Ansys 12.0 keretrendszerben.

A geometriai modell kialakításakor a vizsgált térfogat nyolcadát modelleztük, amelyre a folytonossági kritériumokat peremfeltételekkel definiáltuk.

A geometriai modell a betonnál egy, a vasbeton esetében két szilárdtestet tartalmaz, finom hálózással. A beton modellt a [4] részletesen ismerteti, a vasbeton modellt a 3. ábra mutatja be.

Az eredmények kiértékelésekor a peremfeltételeket változtatva a kialakult minimum és maximum hőmérsékletek időbeni változását vizsgáltuk mindkét modellnél.

\section{Eredmények}

$\mathrm{Az}$ elemzés eredményeképpen megállapítható, hogy mindkét modellnél a hőmérséklet időbeni változása hasonló volt.

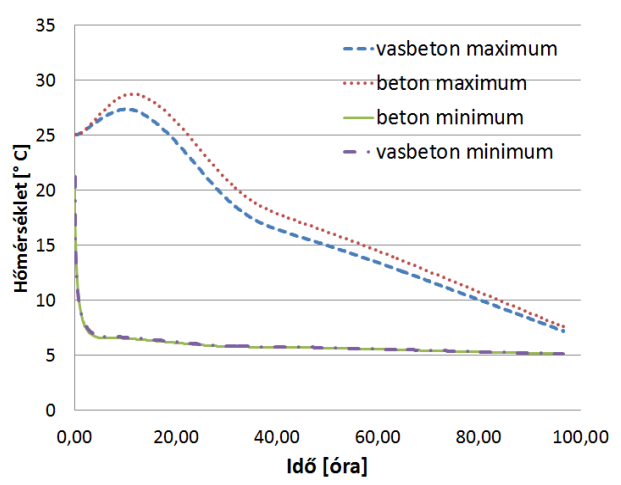

4. ábra. A minimum és maximum hömérsékletek alakulása $h=30 \mathrm{~W} /\left(\mathrm{m}^{2} \mathrm{~K}\right)$, valamint $T=5^{\circ} \mathrm{C}$ esetén az idö függvényében

A geometria középpontjában a legmagasabb, a sarkokban pedig a legalacsonyabb hőmérséklet alakult ki minden kísérleti beállításnál.

A kiemelt példáról (4. ábra) valamint a többi esetről is elmondható, hogy a $\Delta \mathrm{T}$ hömérséklet-különbséget a hőmérsékleti maximumok befolyásolják számottevően, amíg a hőmérsékleti minimumok hatása minimális. Továbbá a beton és a vasbeton modell eredményeinek összehasonlításakor jól látszik, hogy a hőmérsékleti minimumok esetében nincs befolyásoló hatása a betonacé- 
lok jelenlétének. A hőmérsékleti maximumok viszont a két modellnél eltérnek. A betonacélt is tartalmazó modell maximum hőmérsékletei alacsonyabbak, mint a beton modell esetén.

2. táblázat. A maximum hömérsékletek különbsége (vasbeton-beton) adott peremfeltételek mellett az idö függvényében

\begin{tabular}{|l|c|c|}
\hline Perem-feltételek & $\begin{array}{c}\text { Maximum hö- } \\
\text { mérsékletek } \\
\text { különbsége }\left[{ }^{\circ} \mathrm{C}\right]\end{array}$ & $\begin{array}{c}\text { Idő } \\
{[\mathrm{h}]}\end{array}$ \\
\hline $\begin{array}{l}\mathrm{h}=5 \mathrm{~W} / \mathrm{m}^{2} \mathrm{~K} \\
\mathrm{~T}=5^{\circ} \mathrm{C}\end{array}$ & 1,39 & 45,90 \\
\hline $\begin{array}{l}\mathrm{h}=5 \mathrm{~W} / \mathrm{m}^{2} \mathrm{~K} \\
\mathrm{~T}=30^{\circ} \mathrm{C}\end{array}$ & 1,08 & 60,89 \\
\hline $\begin{array}{l}\mathrm{h}=30 \mathrm{~W} / \mathrm{m}^{2} \mathrm{~K} \\
\mathrm{~T}=5{ }^{\circ} \mathrm{C}\end{array}$ & 1,87 & 21,75 \\
\hline $\begin{array}{l}\mathrm{h}=30 \mathrm{~W} / \mathrm{m}^{2} \mathrm{~K} \\
\mathrm{~T}=30^{\circ} \mathrm{C}\end{array}$ & 1,09 & 38,56 \\
\hline
\end{tabular}

A vizsgálat eredményeit betonacéllal erösített és betonacél nélküli modellek esetén a 2. táblázatban foglaltuk össze.

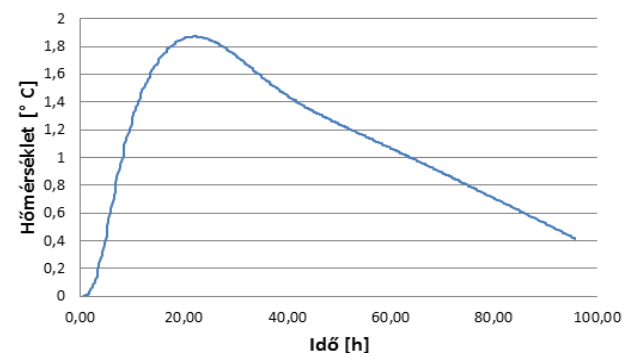

5. ábra. A hömérséklet maximumok hömérséklet különbségeinek alakulása

A kapott eredményekből kiderül, hogy a kísérlettérben a $\mathrm{h}=30 \mathrm{~W} / \mathrm{m}^{2} \mathrm{~K}$ és $\mathrm{T}=5^{\circ} \mathrm{C}$-nál a legnagyobb a modellezéskor kapott maximum hömérsékletek különbsége, amely a 21,75. órában alakul ki. Az 5. ábra a ma- ximális hőmérsékletek különbségét szemlélteti az idő függvényében.

\section{Következtetések}

A vasalt és a vasalatlan modell esetében a minimum hőmérsékletek közötti különbség az adott kísérlettérben elhanyagolható.

A betonacélok hatása hőtani szempontból a maximum hőmérsékletek között már mutat eltérést, a vizsgált betontípus esetében számottevő az adott peremfeltételeknél, mivel a szabvány a repedés elkerülése végett maximum $20^{\circ} \mathrm{C}$ hőmérsékletkülönbséget enged meg. Alacsony környezeti hőmérséklet és magas hőátadási tényező mellett a betonacélok használata hőtani szempontból jelentősen csökkentheti a repedésveszélyt.

A modell térfogata a kísérlettérben állandó volt, továbblépésként a geometria befolyásoló hatását kívánjuk vizsgálni.

\section{Szakirodalmi hivatkozások}

[1] B. A. Klemczak: Modeling thermalshrinkage stresses in early age massive concrete structures, Comparative study of basic models, Archives of civil and mechanical engineering 14, (2014), pp. 721-733.

[2] B. Klemczak, Agnieszka Knoppik-Wróbel: Reinforced concrete tank walls and bridge abutments: Early-age behaviour, analytic approaches and numerical models, Engineering Structures 84 (2015) pp. 233-251

[3] Xiaobin Song, Yeqi Li, Chao Chen, Feng Lin, Susu Shang: Modeling early age RC slab cracking considering time-dependent bond behaviour, Engineering Structures 138 (2017) pp. 27-34

[4] Domonyi Erzsébet, Csizmadia Béla, Telekes Gábor: Tömegbetonok repedési hajlamának elemzése a hömérséklet és a höátadási tényezö függvényében GÉP LXVII: (5-6) pp. 44-47. (2016) 